\title{
Variable and elevated oxygen in the Archean atmosphere
}

\author{
JEFFREY A. STEADMAN ${ }^{1}$, ROSS R. LARGE ${ }^{1}$, NIGEL J. \\ BLAMEY $^{2}$, ROSS CORKREY ${ }^{3}$, AND LEONID V. \\ DANYUSHEVSKY ${ }^{1}$ \\ ${ }^{1}$ CODES (Centre for Ore Deposit and Earth Sciences), \\ University of Tasmania, Private Bag 79, Hobart TAS 7001, \\ Australia; ${ }^{2}$ Department of Earth Sciences, Western \\ University, London ON N6A 5B7, Canada; ${ }^{3}$ Tasmanian \\ Institute of Agriculture, University of Tasmania, Private Bag \\ 98, Hobart TAS 7001, Australia
}

Current estimates of atmospheric oxygen concentrations in the geologic past indicate that the Archean atmosphere was strongly depleted in oxygen $\left(<0.002 \% \mathrm{O}_{2}\right.$, or $<0.01 \%$ of the present atmospheric level [PAL]; [1]). These figures were determined by both geological observations and a series of geochemical proxies involving redox-sensitive trace elements in whole-rock samples of marine carbonaceous shale and/or their isotopic ratios $[2,3]$. However, these proxy techniques have fundamental problems, including a lack of control on isotopic resetting and element deportment.

The use of sedimentary pyrite as a proxy for ocean and atmosphere oxygenation is a novel technique that offers distinct advantages over the standard methods of whole-rock geochemistry and stable isotopes. For example, Se and Co are important redox-sensitive trace elements that predominantly reside in pyrite. LA-ICPMS allows for the selective analysis of Se- and Co-bearing pyrite, which amplifies the signal of these low-level elements [4].

Our data [5] indicate that oxygen rose overall throughout the Paleo-, Meso-, and Neoarchean, from a low of $0.27 \% \mathrm{O}_{2}$ $(1 \% \mathrm{PAL})$ at $3500 \mathrm{Ma}$ to a high of $\sim 5 \% \mathrm{O}_{2}$ at the ArcheanProterozoic boundary (2500 Ma; $25 \%$ PAL). Multiple decreases in $\mathrm{O}_{2}$ concentrations also occurred at set times, with the largest drop at $\sim 2900 \mathrm{Ma}$ (down to $0.2 \% \mathrm{O}_{2}$, or $1 \%$ PAL).

[1] Lyons et al. (2014), Nature 506, 307-315. [2] Cloud (1973), Econ. Geol. 68, 1135-1143. [3] Bekker et al. (2004), Nature 427, 117-120. [4] Large et al. (2014), EPSL 389, 209220. [5] Steadman et al. (2020), Precam. Res., in press. 